\title{
STRATEGI PENGELOLAAN COWORKING SPACE UNTUK MENGHADAPI PERSAINGAN BISNIS \\ (OBJEK STUDI: CONCLAVE WIJAYA, KELURAHAN PETOGONGAN. KECAMATAN KEBAYORAN BARU, JAKARTA SELATAN)
}

\author{
Sinta Setiani ${ }^{1)}$, Suryono Herlambang ${ }^{2)}$, Liong Ju Tjung ${ }^{3)}$ \\ 1)Program Studi S1 PWK, Fakultas Teknik, Universitas Tarumanagara, sintasunggar@gmail.com \\ 2) Program Studi S1 PWK, Fakultas Teknik, Universitas Tarumanagara, s.herlambang@gmail.com \\ 3) Program Studi S1 PWK, Fakultas Teknik, Universitas Tarumanagara, liongjutjung @gmail.com
}

Masuk: 11-08-2020, revisi: 29-09-2020, diterima untuk diterbitkan: 29-09-2020

\begin{abstract}
Abstrak
Conclave Wijaya sudah berdiri sejak tahun 2013 dan diresmikan ditahun 2014, Conclave Wijaya tidak hanya berfokus pada satu tipe fungsi ruang tetapi selain adanya coworking space disana juga dibangun office space, meeting room, event space, auditorium, dan class room. Identifikasi masalah bermula dari pesatnya perkembangan startup dan usaha mikro kecil dan menengah khususnya di Jakarta. Namun seringnya waktu banyak terobosan baru mengenai konsep dan fungsi dari coworking space yang sesuai kebutuhan konsumen dan tentunya dengan harga terjangkau. Walaupun Conclave Wijaya bekerja sama dengan pihak Comma namun Conclave sendiri tidak mengikuti jejak Comma yang hanya memiliki satu fungsi yakni sebagai coworking space. Hal ini yang menjadi tujuan studi dilakukan, pertama untuk membuktikan Conclave Wijaya mampu mencakup dan mewadahi fungsinya sebagai tempat bekerja dan bersantai, kedua untuk mengkaji fasilitas Conclave Wijaya sebagai wadah yang mampu diminati dan menarik pengguna, dan ketiga untuk melihat kekuatan, kelemahan, peluang dan ancaman pada Conclave Wijaya. Agar tercapainya tujuan metode yang digunakan dengan pendekatan kualitatif dapat mendeskripsikan kondisi yang ada pada Conclave Wijaya serta mengindentifikasi aspek yang mempengaruhi keberadaan Conclave Wijaya. Hasil akhir yang dicapai menunjukkan strategi Conclave Wijaya dalam eksistensinya yang terus bertahan ditengah persaingan bisnis coworking space.
\end{abstract}

Kata kunci: Coworking Space; Fungsi; Kondisi

\begin{abstract}
Conclave Wijaya has been established since 2013 and was inaugurated in 2014, Conclave Wijaya is not only focused on one type of function space but in addition to coworking space there is also built office space, meeting rooms, event spaces, auditoriums and class rooms. The identification of problems stems from the rapid development of startups and micro and small businesses, especially in Jakarta. But often times there are many new breakthroughs about the concept and function of coworking space that suits consumers' needs and of course at affordable prices. Although Conclave Wijaya cooperates with Comma, Conclave itself does not follow in the footsteps of Comma, which only has one function, namely as coworking space. This is the purpose of the study, first to prove that Conclave Wijaya is able to cover and accommodate its function as a place to work and relax, second to study the Conclave Wijaya facility as a container that is able to attract and attract users, and third to see strengths, weaknesses, opportunities and threats on Conclave Wijaya. In order to achieve the objectives of the method used with a qualitative approach can describe the conditions that exist in the Conclave Wijaya and identify aspects that affect the existence of the Conclave Wijaya. The final results achieved indicate the strategy of Conclave Wijaya in its existence that continues to survive amid competition in the coworking space business.
\end{abstract}

Keywords: Analysis; Coworking Space; User; Strategy 


\section{PENDAHULUAN}

\section{Latar Belakang}

Pertumbuhan industri kreatif digital dan teknologi serta berkembangnya cara-cara kerja baru membuka peluang penyediaan ruang kerja yang lebih efisien, fleksibel dan murah, atau sesuai dengan kebutuhan. Teknologi tersebut juga punya andil besar dalam meningkatkan pertumbuhan dan perkembangan sektor UKM, entrepreneur, startup (bisnis rintisan berbasis kreatif digital) dan juga freelancer.

Pemilihan kantor yang tepat menjadi salah satu hal yang sangat penting untuk kemajuan dari perusahaan maupun bisnisnya tersebut. Di Jakarta perkantoran memiliki berbagai macam kriteria atau jenis-jenis perkantoran. Banyaknya jenis membuat semakin sulit untuk menentukan tempat terbaik menyewa kantor di Jakarta yang sangat kompetitif. Ditambah dengan harga sewa kantor di Jakarta yang juga bervariasi. Di Jakarta, tidak semua kantor memilik harga sewa yang sama, ada yang memiliki harga fantastis ada pula kantor murah di Jakarta dan kantor murah ini dapat menjadi jawabab bagi para pengusaha yang baru membangun usahanya. Faktor-faktor tersebut, menjadi salah satu alternatif tempat bekerja yang sedang berkembang saat ini yaitu coworking space. Namun dengan perkembangan coworking space dan pertumbuhannya yang semakin menjamur menjadikan usaha dibidang ini cukup kompetitif. Hal ini yang menjadi perhatian penulis perlu adanya strategi pengelolaan dalam menghadapi persaingan usaha coworking space. Conclave Wijaya menjadi pilihan objek studi dikarenakan adanya hubungan kerja dengan coworking space Comma yang dimana coworking space pertama di Jakarta ditambah dengan Conclave Wijaya sendiri telah lama berdiri hampir 7 tahun dan khususnya di Kebayoran Baru menjadi coworking space tertua dan masih ada sampai sekarang. Conclave Wijaya merupakan coworking space yang terletak di Jl.Wijaya I no.5c RT.7/RW.4, Petogonga Kecamatan Kebayoran Baru Kota Jakarta Selatan.

Conclave Wijaya berdiri diatas bangunan yang memiliki fungsi perkantoran dan perdagangan dengan code berwarna ungu. Conclave Wijaya sendir awal berdiri 2013 namun peremiannya 2014. Conclave Wijaya memiliki 3 lantai dan 1 basement dengan occupancy rate pada tahun Q4 2019 sebesar 100 \% dan pada Januari - Maret 2020 65\%. Menurut hasil wawancara dengan bagian admin sekaligu reception penurunan terjadi dikarenakan kebanyakan pengguna coworking space menyewa ketika adanya proyek yang biasanya dilakukan 3 sampai 6 bulan, dan biasanya akan terjadi lonjakan occupancy rate pada Q2 sampai pada Q4 atau akhir tahun. Bangunan Conclave Wijaya sendiri memiliki gaya konsep bangunan indrustrial yang menunjukkan sifat unfinish namun ini juga menjadi faktor penting ketertarikan pengguna untuk memilik Conclave Wijaya sebagai tempat bekerja dengan nuansa yang santai.

\section{Rumusan Permasalahan}

Perkembangan coworking space bermula di Jakarta tepat di Kebayoran Baru yang bernama Comma menjadi coworking space pertama. Sampai sekarang pertumbuhan coworking space tetap ada dan terus berkembang di Kebayoran Baru. Rumusan masalah yang dikaji oleh peneliti adalah bagaimana coworking space yang sudah lama berada dikawasan Kebayoran Baru terus ada dan juga mampu meningkatkan eksistensinya sehingga pemilihan objek studi di Conclave Wijaya menjadi pilihan penulis untuk mengulik dari rumusan masalah tersebut dengan melihat dari sisi strategi pengelolaannya.

\section{Tujuan}

Berikut tujuan untuk melihat strategi pengelolaan coworking space Conclave Wijaya di Kebayoran Baru sehingga dapat menjadi acuan ataupun market leader bagi pihak swasta atau pengembang maupun pemerintah, dengan cara:

a. Membuktikan Conclave Wijaya mampu memenuhi fungsinya untuk dijadikan tempat bekerja dan bersantai melihat dari identifikasi masalah yang ada.

b. Mengkaji fasilitas Conclave Wijaya sebagai tempat yang dapat dijadikan coworking space 
yang menarik dan diminati sehingga tetap memperhatikan fungsinya sebagai tempat bekerja atau kantor.

c. Melihat dari faktor internal yakni dengan berfokus kepada kekuatan dan kelemahan serta melihat dari sisi peluang dan ancaman pada faktor ekternal pada Conclave Wijaya.

\section{KAJIAN LITERATUR}

Coworking space merupakan wadah bagi orang-orang untuk bertemu dan saling berbagi pengalaman mereka masing-masing dan tidak sedikit menjadikan mereka untuk menciptakan inovasi baru dalam dunia kerja dengan tujuan yang sama.

Coworking space didefinisikan sebagai tempat kerja beragam kelompok freelancer, pekerja jarak jauh, dan profesional independen lain yang bekerja sama dalam pengaturan komunal (Gretchen M. Spreitzer, 2017).

Fungsi dari coworking space yakni dengan tersediakan ruang kerja dengan bentuk yang berbeda namun tetap berfokus pada jenis ruang kerja yang menunjukkan fleksibilitas, kolaborasi, inovasi, keterbukaan, pengalaman dan pengetahuan. Tujuan tersebut bertujuan agar tercapainya sebuah fungsi coworking space yaitu (I Gusti Agung Yoga Prasetya, 2018, hal. 18):

a. Membangun sebuah komunitas kerja untuk para coworker.

b. Meningkatkan peluang bagi para coworkers dari bersosialisasi.

c. Suasana kerja yang lebih kondusif dan kreatif.

d. Bekerja menjadi lebih produktif, efisien, dan termotivasi.

e. Memperluas jaringan personal maupun profesional dengan cepat.

Standarisasi Coworking Space, Ruang menurut Duygu Ergin dibagi menjadi 4, yaitu:

Primary Spaces dengan primary spaces atau ruang utama pada coworking spaces ini adalah coworking space.

Service Spaces, Beberapa contoh dari services spaces atau ruang layanan adalah pusat kegiatan, perpustakaan, ruang pelatihan, auditorium, ruang berkas, ruang untuk melakukan pencetakan atau print.

Hidden Service, beberapa contoh ruang yang masuk kedalam Hidden Service atau ruang layanan tersembunyi adalah ruang workshop, ruang staff, ruang penyimpanan, ruang pekerja, dan lainlain.

Secondary Spaces atau yang dimaksud dengan ruang utama kedua mencakup 3 area, yaitu, area komersial, area sosial dan area olahraga. Sebagai contoh adalah restoran, café, toko, ruang club, bar, pusat kesehatan, dan lain-lain.

Klasifikasi Coworking Space dibagi menjadi lima klasifikasi utama yaitu, midsize and big community coworking space, small community coworking space, corporate powered coworking space, university related coworking space, dan popup coworking space (Schuermann, 2014, hal. 28).

Kegiatan yang dilakukan di dalam berbagai tipe coworking space kurang lebih sama dengan kegiatan perkantoran di rental office namun dengan perbedaan pola kerja yang lebih fleksibel dan dinamis serta ruang ruang yang digunakan dengan sistem berbagi pakai untuk menekan pembiayaan. (Dugyu, 2014) merespon 13 perkembangan pola kerja dengan membuat klasifikasi aktivitas di dalam coworking space yang dijelaskan melalui table dibawah ini. 
Tabel 1. Klasifikasi Aktivitas Berdasarkan Jumlah Pengguna

\begin{tabular}{|c|c|}
\hline User & Activity \\
\hline Solo & $\begin{array}{l}\text { Writing, drawing, telephoning, selling, dealing, thinking, } \\
\text { reading, filling, computing, researching }\end{array}$ \\
\hline Collevive & Selling, dealing, researching, filling \\
\hline Group & $\begin{array}{l}\text { Teaching, counselling, monitoring, interviewing, meeting, teaw } \\
\text { working, brainstorming, informing, briefing, conferencing }\end{array}$ \\
\hline Congenial & $\begin{array}{l}\text { Mailing, circulating, paper processing, getting suppliesm filling, } \\
\text { personal care, coffee making, brown-bagging, working lauches }\end{array}$ \\
\hline Socializing & Eating, entertaining, chatting, smoking, exercising \\
\hline
\end{tabular}

\section{METODE}

Pada penelitian ini penulis melakukan pedekatan kualitatif dan kuantatif dimana penulis melakukan pengamatan secara langsung untuk dapat mendeskripsikannya secar terperinci dan juga mengumpulkan data berbentuk numerik. Lokasi penelitian berada di Conclave Wijaya J.Wijaya I no.5c RT.7/RW.4, Petogonga Kecamatan Kebayoran Baru Kota Jakarta Selatan. Jenis data yang digunakan yaitu data primer dan data sekunder. Data primer merupakan sumber data yang diperoleh langsung dari objek studi dan data sekunder yang merupakan sumber data penelitian yang dapat diperoleh secara tidak langsung. Teknik pengumpulan data primer melalui wawancara kepada pekerja dan general manager Conclave Wijaya serta melakukan survei objek studi dan menyebarkan kuesioner melalui google form dikarenakan adanya wabah pandemik Corona. Sedangkan teknik pengumpulan data sekunder data diperolah penulis dari dokumentasi / arsip dari Conclave Wijaya serta dari internet dan jurnal serta tesis beberapa sumber untuk dapat menjadi data pendukung dalam penelitian ini.

Analisis yang digunakan adalah :

a. Analisis kondisi eksisting ini untuk melihat kondisi eksisting pengelolaan baik secara fisik maupun nonfisik. Tujuannya ialah melihat potensi dan permasalahan pada pengelolaan yang terjadi di masa sekarang khususnya pada fasilitas dan organisasi yang terdapat di objek studi. Analisis ini menggunakan metode deskriptif.

b. Analisis preferensi pengunjung bertujuan untuk mengetahui karakteristik pengunjung yang datang pada objek studi, padangan pengunjung terhadap kondisi dan pengelolaan objek studi serta tingkat kepuasan pengunjung. Analisis preferensi pengunjung menggunakan metode deskriptif, skala likert dan diagram cartesius.

c. Analisis strategi pengelolaan ialah dengan cara melihat berbagai hasil analisis sebelumnya terkait pengelolaan dan setelah itu merumuskan masalah serta potensi dari keseluruhan analisis yang ada kemudian akhirnya mengeluarkan strategi pengelolaan beradasarkan masalah dan potensi tersebut. Metode yang digunakan ialah metode SWOT.

\section{DISKUSI DAN HASIL}

\section{Kondisi Eksisting Conclave Wijaya}

Bangunan Conclave Wijaya memiliki 3 lantai dan 1 basement, dimana setiap lantai memiliki fungsinya masing-masing namun untuk penggunaan beberapa jenis ruang memiliki kesamaan fungsi. Fungsi dari ruangan ini menjadi salah satu penunjang bagi pengguna coworking space Conclave Wijaya. Dengan adanya bermacam-macam fungsi dari ruangan dapat membantu pengguna menjadi lebih mudah dalam berkegiatan di coworking space Conclave Wijaya. Berikut ini beberapa fungsi ruangan perlantai: 
a. Basement

Pada basement terdapat:

- Ruang mesin lift

- Gudang

- Office Space yang memiliki bermacam daya tampung 1 - 20 orang.

- $\quad$ Akses Lift (tidak berfungsi)

- Parking area

- Akses melalui tangga

- Toilet

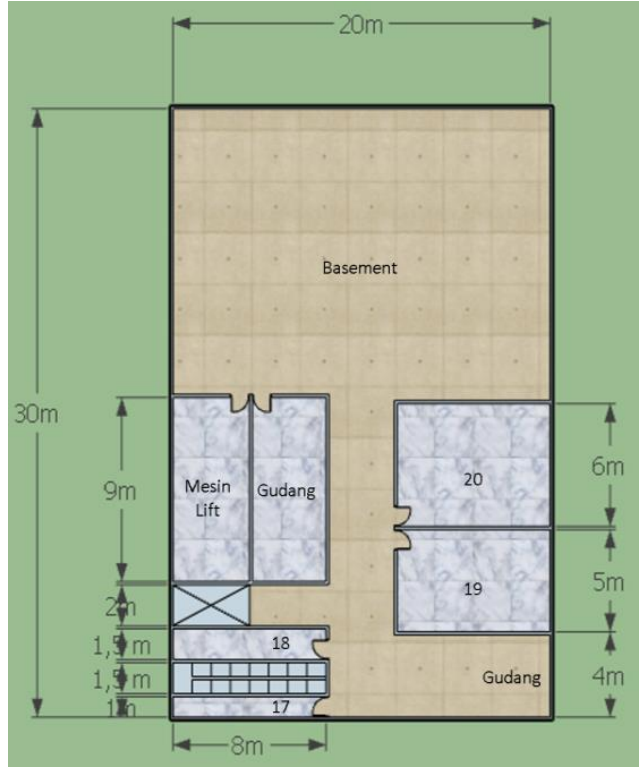

Gambar 1. Denah Lantai Basement Sumber: Olahan Penulis

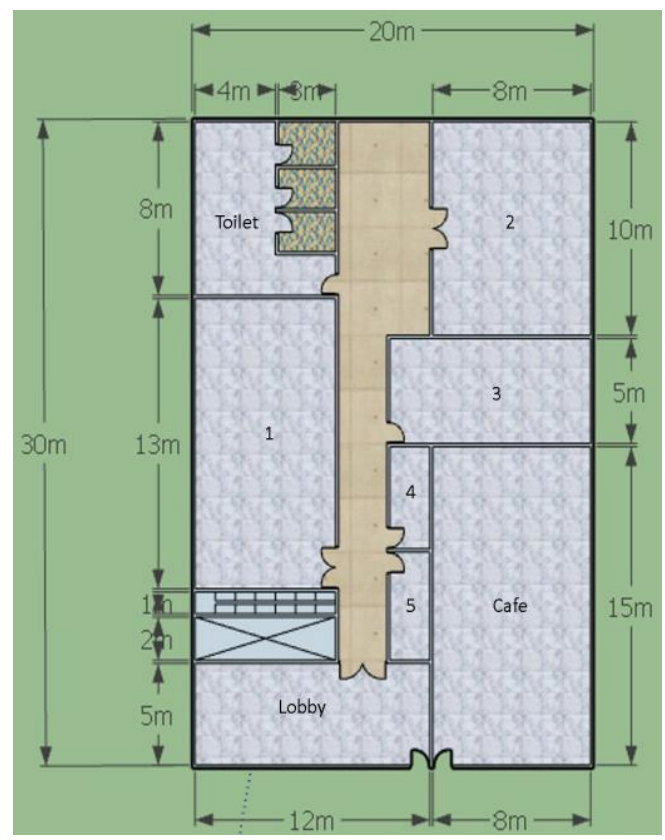

Gambar 2. Denah Lantai 1

Sumber: Olahan Penulis 
c. Lantai 3

Pada lantai 3 terdapat:

- Meeting room

- Office space

- Toilet

- Akses lift (tidak berfungsi)

- Akses memalui tangga

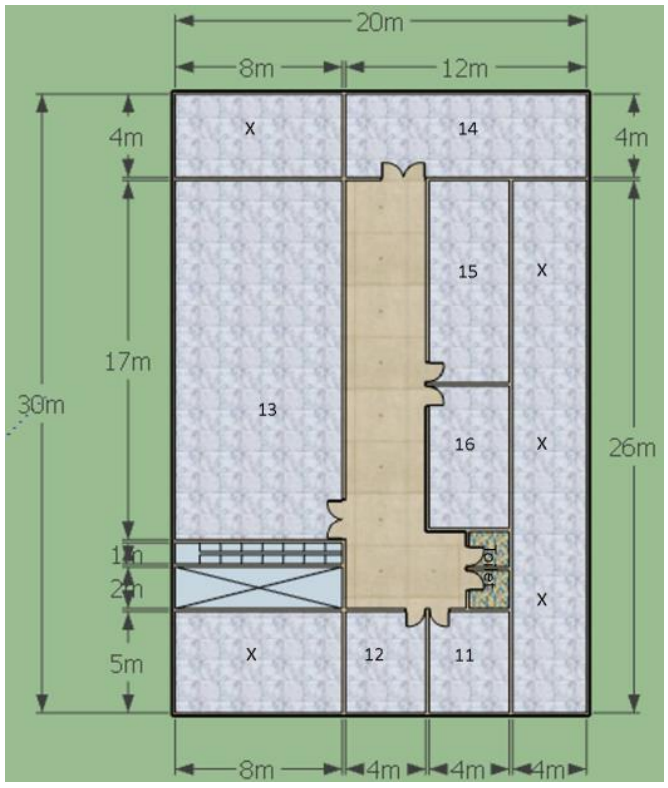

Gambar 3. Denah Lantai 3

Sumber: Olahan Penulis

d. Lantai 2

Pada lantai 2 terdapat:

- Auditorium

- Office space

- Meeting room

- Coworking space (terdapat juga khusus smooking area)

- Akses lift (tidak berfungsi)

- Akses memalui tangga

- Toilet dan kamar mandi

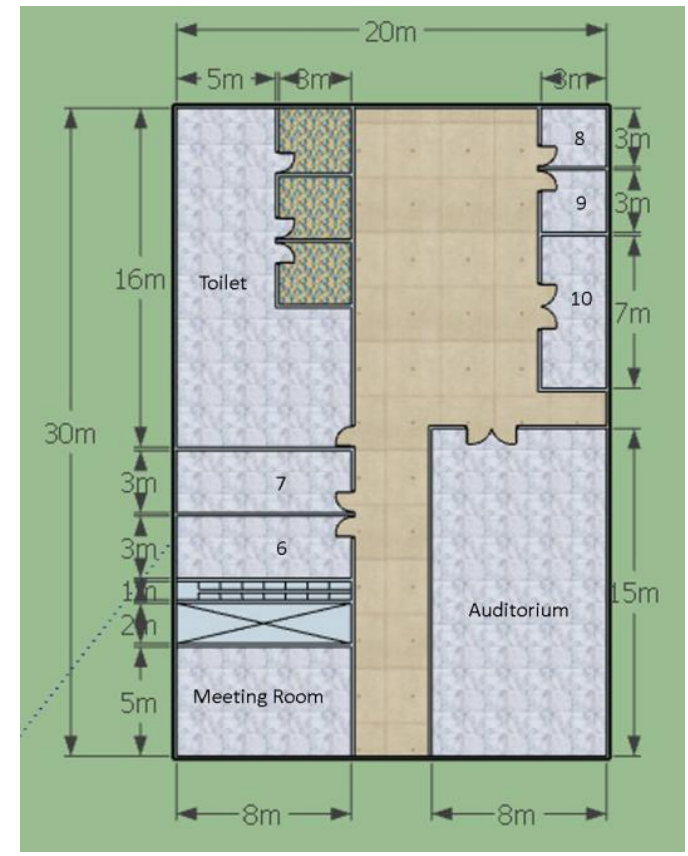

Gambar 4. Denah Lantai 2

Sumber: Olahan Penulis

\section{Pesaing Bisnis Conclave Wijaya}

Conclave Wijaya tentu memiliki pesaing yang kompetitif dibidang coworking space. Namun diantara yang masih beroperasi hanya 3 coworking space yakni Tierspace, Cohive Senopati dan Etzubizi. Pada bagian ini menunjukkan pesaing-pesaing bisnis coworking space Conclave Wijaya dapat dilihat pada gambar berikut: 

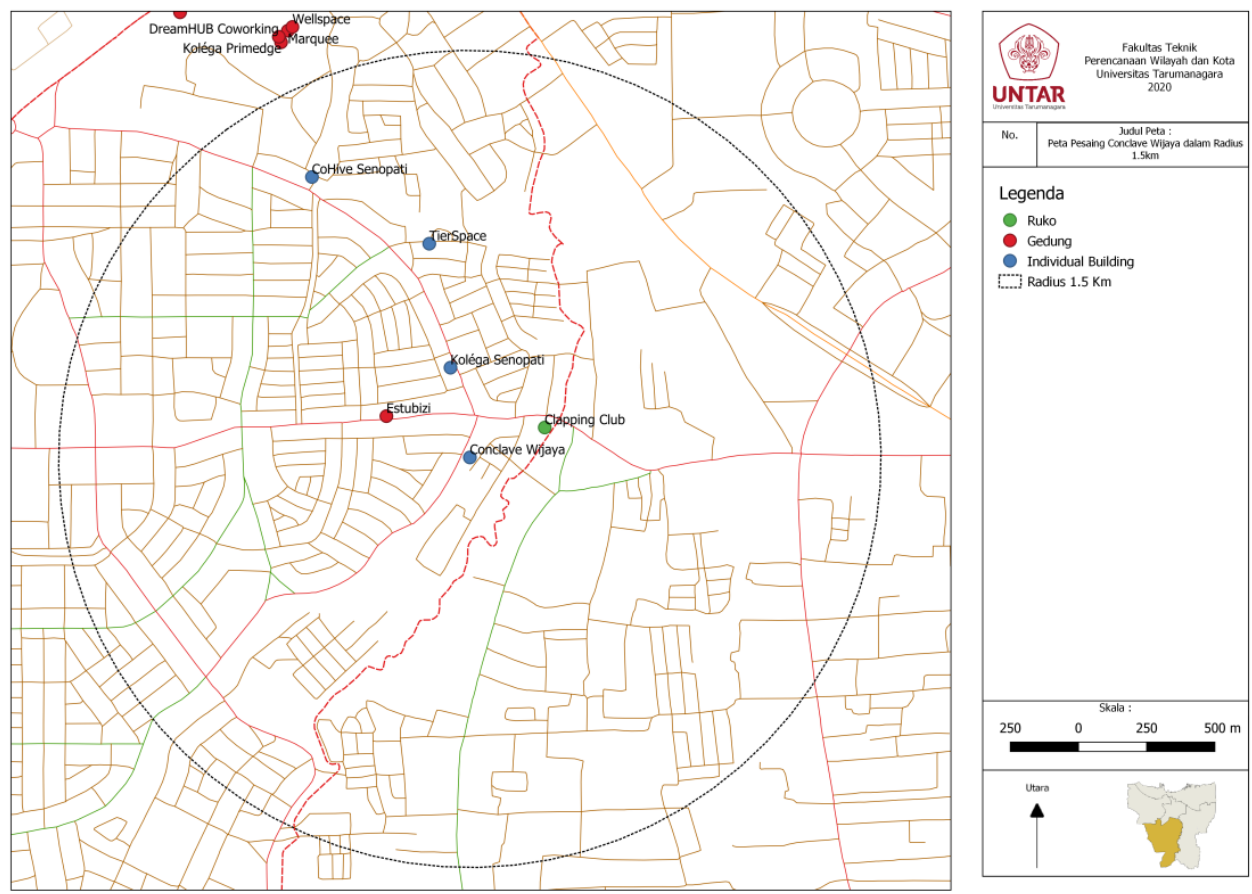

Gambar 5. Peta Pesaing Conclave Wijaya Dalam Radius 1.5 km Sumber: Olahan Penulis

\section{Persepsi Pengunjung Terhadap Conclave Wijaya}

Kriteria berdasarkan penilaian pengunjung Conclave Wijaya untuk kemudian diskoring mengidentifikasi posisi keputusan penilaian persepsi pengunjung dan keputusan penilaian didasarkan pada persentase pencapaian. Berdasarkan posisi (indikator) pengambilan keputusan dan dibandingkan dengan nilai rata-rata persentase tiap pertanyaan persepsi maka hasil persepsi Conclave Wijaya dapat dijabarkan pada berikut ini.

Berdasarkan jumlah minimal responden 84 orang, penulis mengambil total sampel yang tersebesar sebanyak 86 responden. Berdasarkan hasil penelitian maka hasil yang dikumpulkan dapat dikelompokkan menjadi beberapa bagian yaitu sebagai berikut:

- Profil dan karakteristik pengunjung

- Kunjungan

- Preferensi pengunjung

Tabel 2. Penilaian Persepsi Pengunjung Terhadap Strategi Bersaing Coworking Space Conclave Wijaya

\begin{tabular}{lllllllll}
\hline No & Kriteria Penilaian & STS & TS & S & SS & Total & $\%$ & Keterangan \\
\hline P1 & $\begin{array}{l}\text { Conclave Wijaya menjadi tempat } \\
\text { mendapatkan pengalaman yang baru } \\
\text { dalam suasana bekerja/belajar. }\end{array}$ & 0 & 2 & 201 & 72 & 275 & $80 \%$ & Sangat Baik \\
\hline P2 & $\begin{array}{l}\text { Suasana coworking space Conclave } \\
\text { Wijaya yang tenang dan nyaman dapat } \\
\text { membantu anda menyelesaikan tugas } \\
\text { atau pekerjaan dengan mudah. }\end{array}$ & 6 & 198 & 68 & 272 & $79 \%$ & Sangat Baik \\
\hline P3 & $\begin{array}{l}\text { Bekerja/berkantor di coworking space } \\
\text { Conclave Wijaya membuat relasi semakin } \\
\text { bertambah. }\end{array}$ & 32 & 162 & 64 & 258 & $75 \%$ & Sangat Baik \\
\hline P4 & $\begin{array}{l}\text { Pihak Conclave Wijaya selalu memberikan } \\
\text { pelayan yang maksimal pada pengguna. }\end{array}$ & 0 & 8 & 216 & 40 & 264 & $77 \%$ & Sangat Baik \\
\hline
\end{tabular}




\begin{tabular}{|c|c|c|c|c|c|c|c|c|}
\hline P5 & $\begin{array}{l}\text { Layanan call center, email ataupun sosial } \\
\text { media coworking space Conclave Wijaya } \\
\text { sudah melayani secara maksimal. }\end{array}$ & 0 & 14 & 207 & 40 & 261 & $76 \%$ & Sangat Baik \\
\hline P6 & $\begin{array}{l}\text { Harga sewa coworking space Conclave } \\
\text { Wijaya termasuk dalam kategori harga } \\
\text { rata-rata sewa coworking space pada } \\
\text { umumnya. }\end{array}$ & 0 & 4 & 231 & 28 & 263 & $76 \%$ & Sangat Baik \\
\hline P7 & $\begin{array}{l}\text { Fasilitas yang lengkap membuat nyaman } \\
\text { berlama-lama di coworking space } \\
\text { Conclave Wijaya. }\end{array}$ & 0 & 2 & 201 & 72 & 275 & $80 \%$ & Sangat Baik \\
\hline P8 & $\begin{array}{l}\text { Suasana yang nyaman di coworking space } \\
\text { Conclave Wijaya meningkatkan mood } \\
\text { dalam menyelesaikan pekerjaan atau } \\
\text { tugas belajar. }\end{array}$ & 0 & 4 & 195 & 76 & 275 & $80 \%$ & Sangat Baik \\
\hline P9 & $\begin{array}{l}\text { Dapat dengan mudah untuk menyewa } \\
\text { lansung coworking space di Conclave } \\
\text { Wijaya. }\end{array}$ & 0 & 4 & 195 & 76 & 275 & $80 \%$ & Sangat Baik \\
\hline P10 & $\begin{array}{l}\text { Posisi coworking space Conclave Wijaya } \\
\text { yang berada di stand alone/bangunan } \\
\text { tunggal memiliki kemudahan untuk } \\
\text { diakses. }\end{array}$ & 0 & 2 & 213 & 56 & 271 & $79 \%$ & Sangat Baik \\
\hline
\end{tabular}

Sumber: Olahan Penulis, 2020

Berikut ini kesimpulan dari hasil penyebaran kuesioner yang dilakukkan secara online denngan menggunakan media google form. Pada tabel menunjukkan kesimpulan dari profil atau karateristik pengunjung kemudia kunjungannya seperti waktu kunjungan dan alat transportasi serta yang terakhir persepsi pengunjung mengenai kondisi Conclave Wijaya.

Tabel 3. Kesimpulan Karakteristik, Kujunngan dan Persepsi Pengunjung

\begin{tabular}{lll}
\hline No & \multicolumn{1}{c}{ Keterangan } & \multicolumn{1}{c}{ Pesimpulan } \\
\hline 1 & Jenis Kelamin & Pengunjung dominan berjenis kelamin perempuan \\
\hline 2 & Usia & Pengunjung dominan berusia 20-29 tahun \\
\hline 3 & Domisili & Pengunjung dominan berdomisili di Jakarta Selatan \\
\hline 4 & Pekerjaan atau profesi & Pengunjung dominan pelajar/mahasiswa \\
\hline 5 & Membership & Pengunjung dominan bukan anggota member \\
\hline 6 & Tujuang Kunjungan & Kunjungan \\
\hline 7 & Teman Kunjungan & Pengunjung dominan memiliki tujuan belajar \\
\hline 9 & Lama Waktu Kunjungan & Pengunjung dominan pergi bersama teman \\
\hline 10 & Intensitas Kunjungan & $\begin{array}{l}\text { Pengunjung dominan menghabiskan waktu 2-7 jam } \\
\text { saja }\end{array}$ \\
\hline 11 & Transpotasi yang Digunakan berkunjung jika ada keperluan & $\begin{array}{l}\text { Pengunjung dominan menggunakan transportasi } \\
\text { umum }\end{array}$ \\
\hline 12 & Kebutuhan Fasilitas & $\begin{array}{l}\text { Pengunjung dominan menggunakan ojek online } \\
\text { sebagai alat transportasinya }\end{array}$ \\
\hline & & $\begin{array}{l}\text { Pengunjung dominan mengatakan sudah memenuhi } \\
\text { kriteria kebutuhan fasilitas }\end{array}$ \\
\hline 13 & $\begin{array}{l}\text { Hasil persepsi pengunjung mengatakan bahwa 10 kategori yang dinilai memiliki } \\
\text { kriteria sangat baik dengan 4 kategori teratas menurut persentasenya yakni }\end{array}$ \\
\hline
\end{tabular}


pengelaman baru, kelengkapan fasilitas, kenyamanan, dan kemudahan penyewaan atau pelayanan

Sumber: Olahan Penulis, 2020

\section{Strategi Pengelolaan Untuk Menghadapi Persaingan}

Pengelolaan manajemen Conclave secara umum dibagi menjadi 3 bagian yakni keuangan, marketing, dan general manager. Dari CEO \& founder sampai kepada masing-masing coworking space Conclave yang tersebar di area Jakarta yakni Conclave Wijaya, Conclave Arteri, Conclave Simatupang, dan Conclave SCBD. Untuk Conlave Wijaya sendiri sistem tatanan kerjanya dimulai dari GM kemudian staf admin sekaligus bagian reception dan dibantu 2 orang tenaga kebersihan.

Berdasarkan hasil dari beberapa analisis maka terdapat beberapa strategi pengelolaan yang dapat diterapkan terhadap Conclave Wijaya dalam bentuk analisis SWOT. Berikut ini adalah usulan strategi:

Tabel 4. Strategi SWOT

\begin{tabular}{|c|c|c|}
\hline Strategi & Strengths & Weeknesses \\
\hline & 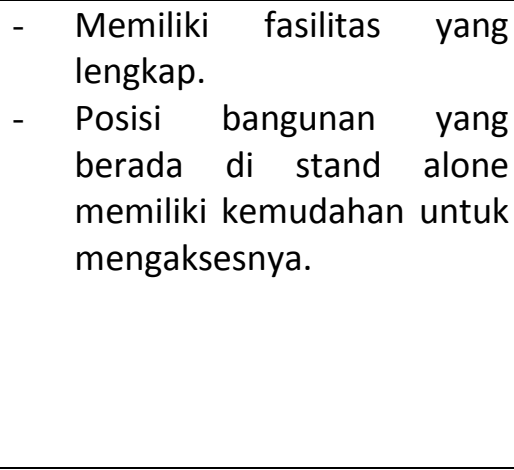 & $\begin{array}{l}\text { - Kondisi eksisting fasilitas } \\
\text { toilet dan kamar mandi } \\
\text { yang kurang bersih dan } \\
\text { berbau. } \\
\text { - Pengelolaan masih kurang } \\
\text { baik dikarenakan tidak } \\
\text { adanya database } \\
\text { pengunjung khususnya } \\
\text { occupancy rate secara } \\
\text { detail. }\end{array}$ \\
\hline Opportunities & $s-0$ & $w-0$ \\
\hline 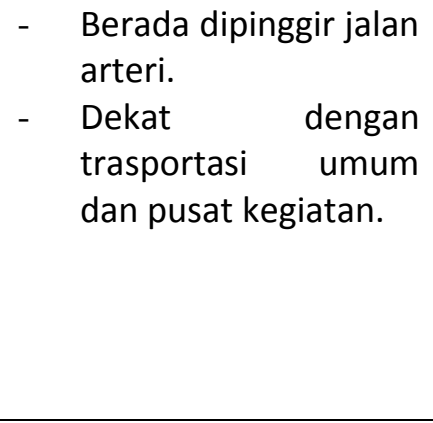 & 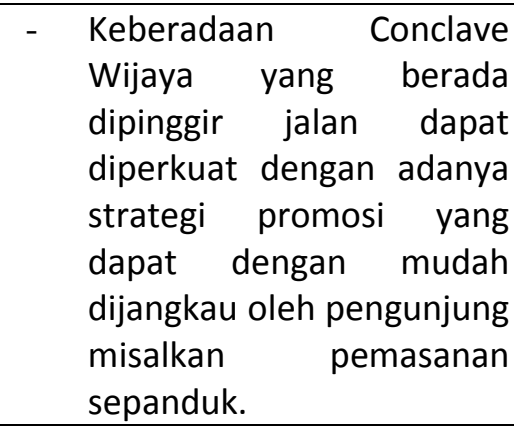 & $\begin{array}{lr}\text { - } & \text { Meningkatkan strategi } \\
\text { peningkatan mutu } & \text { menjaga } \\
\text { dengan yan } & \text { mebersihan pada Conclave } \\
\text { Wijaya yang } & \text { memperhatikan setiap sisi } \\
\text { man ruang, apalagi dengan } \\
\text { daberadaannya yang } \\
\text { mudah diakses. }\end{array}$ \\
\hline Threats & $S-T$ & $\mathbf{W}-\mathbf{T}$ \\
\hline $\begin{array}{l}\text { - } \text { Kondisi adanya } \\
\text { pandemik Covid-19. } \\
\text { - } \\
\text { Pesaing yang sama- } \\
\text { sama kompetitif dan } \\
\text { memiliki inovasi yang } \\
\text { berbeda-beda. }\end{array}$ & $\begin{array}{l}\text { - Meningkatkan strategi } \\
\text { fasilitas atau layanan } \\
\text { dengan sasaran pasar yang } \\
\text { lebih spesifik misalkan } \\
\text { memperhatikan } \\
\text { permintaan konsumen } \\
\text { dengan kondisi yang ada } \\
\text { contohnya ditengah covid- } \\
19 . \\
\text { Meningkatkan kemudahan } \\
\text { strategi akses ke lokasi }\end{array}$ & $\begin{array}{l}\text { - Perlu melakukan strategi } \\
\text { merebut pasar dengan } \\
\text { berbagai bentuk strategi } \\
\text { pemasaran agar dapat } \\
\text { bersaing dengan } \\
\text { kompetitor sehingga } \\
\text { perlu adanya standar } \\
\text { target yang harusnya } \\
\text { tersewakan dari } \\
\text { perusahaan pusat. }\end{array}$ \\
\hline
\end{tabular}


dengan menyediakan drop out khusus bagi pengguna ojek online.

$\begin{array}{lr}\text { Perlu melakukan strategi } \\ \text { positioning } & \text { dan } \\ \text { rebranding } & \text { khusunya } \\ \text { produk/ruang } & \text { kerja } \\ \text { terbaru r seperti } & \text { srotokol } \\ \text { memperhatikan } & \text { proto } \\ \text { kesehatan covid-19 agar } \\ \text { dapat menjadi market } \\ \text { leader. }\end{array}$

Sumber: Olahan Penulis, 2020

Usulan strategi berdasarkan table di atas yaitu:

a. Keberadaan Conclave Wijaya yang berada dipinggir jalan dapat diperkuat dengan adanya strategi promosi yang dapat dengan mudah dijangkau oleh pengunjung misalkan pemasanan sepanduk.

b. Meningkatkan strategi peningkatan mutu dengan menjaga kebersihan pada Conclave Wijaya yang memperhatikan setiap sisi dan ruang, apalagi dengan keberadaannya yang mudah diakses.

c. Meningkatkan strategi fasilitas atau layanan dengan sasaran pasar yang lebih spesifik misalkan memperhatikan permintaan konsumen dengan kondisi yang ada contohnya ditengah covid-19.

d. Meningkatkan kemudahan strategi akses ke lokasi dengan menyediakan drop out khusus bagi pengguna ojek online.

e. Perlu melakukan strategi merebut pasar dengan berbagai bentuk strategi pemasaran agar dapat bersaing dengan kompetitor sehingga perlu adanya standar target yang harusnya tersewakan dari perusahaan pusat.

f. Perlu melakukan strategi positioning dan rebranding khusunya produk/ruang kerja terbaru seperti memperhatikan protokol kesehatan covid-19 agar dapat menjadi market leader.

\section{KESIMPULAN DAN SARAN}

\section{Kesimpulan}

Tingginya permintaan untuk ruang kerja dengan model yang efesien dan kolaboratif menjadikan keberadaan coworking space semakin mejamur dan bahwa memiliki inovasi yang beragam agar dapat menjadi market leader dari coworking space. Namun dengan seiringnya waktu banyak juga yang tidak mampu bersaing dengan pasar sehingga pada akhirnya tutup. Hal ini yang menjadi perhatian penulis dengan memilih Conclave Wijaya sebagai objek studi dimana coworking space dengannya pada masa itu banyak yang sudah tutup atau tidak mampu melanjutkan usahanya lagi. Kenyataan lain dari Conclave Wijaya dengan keberadaan yang hampir 8 tahun berdiri, Conclave Wijaya mampu bertahan dan memiliki eksistensi dalam dunia coworking space khususnya di Jakarta. Melihat hal ini, penulis melakukan studi lebih jauh dengan menganalisis strategi kebertahanan Conclave Wijaya dalam bisnis coworking space.

Namun ditengah perkembangan coworking space yang semakin berkembang tentunya hal ini perlu menjadi perhatian dari pihak Conclave Wijaya untuk terus mempersiapkan strategi yang mampu menarik dan menguasai pasar coworking space khususnya di Kebayoran Baru, Jakarta Selatan. Dapat dilihat dengan kondisi seperti sekarang terjadi penurunan occupancy rate, hal ini yang harusnya menajdi perhatian pihak manajemen untuk mempersiapkan segala bentuk strategi agar dapat mempertahankan nama Conclave Wijaya dipasaran. Salah satu strategi yang dapat dilakukan adalah dengan melakukan strategi positioning dan rebranding khusunya produk seperti ruang kerja dengan inovasi terbaru seperti memperhatikan protokol kesehatan ditengah pandemik covid-19 agar dapat menjadi market leader dimana Conclave Wi. 


\section{Saran}

Conclave Wijaya perlu melakukan peningkatan strategi bersaing dengan para kompetitor agar dapat menjadi market leader pasar coworking space salah satunya dnega melakukan berbagai usaha strageti pemasaran salah satunya perusahaan pusat harus menuntukan target occupancy rate. Strategi bersaing yang perlu dilakukan adalah positioning dan rebranding produk atau ruang kerja jenis baru melihat dari kondisi yang ada saat ini ditengah pandemik covid-19 dimana para customer sangat membutuhkan ruang kerja yang sangat memperhatikan protokol kesehatan covid-19.

Untuk menjadikan market leader perlu memperhatikan strategi lokasi, pelayanan, mutu dan promo hal ini sangat penting diperhatikan oleh pihak Conclave Wijaya. Khususnya pihak manajemen juga harus memperhatikan kondisi-kondisi pasar dan temuan ini dalam usaha meningkatkan strategi bersaing Conclave Wijaya dan juga dapat meningkatkan strategi pemasaran agar dapat menjadi market leader dan Conclave Wijaya mampu berhadapan dengan kondisi persaingan yang ketat saat ini.

\section{REFERENSI}

The Co-Working space concept. (2009).

Coworking in the city. (2015). Ephemera Jurnal, 122.

Diffily, S. (2006). The Website Manager's Handbook.

Dugyu. (2013). How to Create a Co-Working Space Handbook.

Gandini, A. (2015). The rise of coworking spaces: A literature review. Retrieved from http://www.ephemerajournal.org:

http://www.ephemerajournal.org/contribution/rise-coworking-spaces-literaturereview

Gupta, P. A. (2009). The Co-Working space. Retrieved from https://www.iima.ac.in: https://www.iima.ac.in/c/document library/get file?uuid=029aa576-2508-4974-808c91df12ab6c5c\&groupld=642050

Merker, J. (2015). Coworking in the city. Retrieved from http://www.ephemerajournal.org/contribution/coworkingcity?utm_content=buffer7ea1a\&utm_medium=social\&utm_source=facebook.com\&ut m_campaign=buffer: openaccess.city.ac.uk/id/eprint/14478/

Schuermann, M. (2014). Coworking Space: A Potent Business Model for Plug 'n Play and Indie Workers.

SINTA. (2015). BAB II Pemahaman Tentang Co-Working Space. Retrieved from https://sinta.unud.ac.id/: https://sinta.unud.ac.id/uploads/wisuda/1204205075-3BAB\%202.pdf

Spreitzer, G. M. (2017). Co-constructing a Sense of Community at Work: The Emergence of Community in Coworking Spaces.

Stumpf, C. (2013). Creativity \& Space The Power Of In Coworking Space. 
